\title{
The Evaluation of CT Images for COVID-19 Prior to Reporting of the First Case
}

\author{
İlk Vakanın Raporlanmasından Önce Bilgisayarlı Tomografi Görüntülerinin COVID-19 \\ için Değerlendirilmesi
}

\author{
Adnan ÖZDEMIR ${ }^{1}$ Selmin Perihan KöMÜRCÜ ERKMEN ${ }^{2}$ Pelin Zeynep BEKIN SARIKAYA ${ }^{1}$ (iD \\ Irfan KARAHAN ${ }^{3}$
}

$\underline{\mathbf{O z}}$

Amaç: Yüksek tanı koyma oranları sahip BT görüntüleri ile hastalığın başlangıç tarihinin doğruluğunu değerlendirmek mümkündür. Çalışmamızın amacı ülkemizde PCR ile Covid-19 tanısı konulmadan önceki tarihlerde hastalığın var olma ihtimalini görüntüleme bulguları ile değerlendirmektir.

Araçlar ve Yöntem: Ülkemizde PCR ile ilk Covid-19 tanısı 11 Mart 2020'de, ilimizde ise 26 Mart 2020 tarihinde konulmuştur. 26 Mart 2020 tarihinden geriye doğru 45 günlük bir dönem ile bir önceki yıl aynı dönemde Toraks BT'leri çekilen toplam hastalar çalışmaya dahil edildi. Görüntüler Kuzey Amerika Radyoloji Derneği konsensus beyanına göre 2 radyolog tarafından değerlendirildi. Hastalığın önceden var olup olmadığını daha yüksek doğrulukla değerlendirmek amacıyla BT bulgularına göre tipik ve kararsız ile atipik ve negatif pnömoni olmak üzere iki gruba ayrıldı.

Bulgular: Pandemi öncesi dönemde toraks BT'si çekilen 2019 yılından 365 hasta ile 2020 yllından 137 hasta olmak üzere toplam 502 hasta mevcut idi. 2019 ve 2020 yıllarındaki pnömoni için negatif subgrubları karşılaştırıldığında istatistiksel olarak anlamlı fark vardı $(\mathrm{p}<0.05)$.

Sonuç: Çalışmamızda covid öncesi dönemde BT bulgularına göre tipik COVID-19 olan hasta sayısı bir önceki yılla benzer şekilde saptanmıştır. Bu durum ülkemizde hastalığın belirtilen tarihten daha önce başlamadığına dair bir gösterge olabilir.

Anahtar Kelimeler: bilgisayarlı tomografi; COVID-19; hastalık raporlama; tanısal

\section{ABSTRACT}

Purpose: It is possible to evaluate the accuracy of the onset date of the disease with CT images with high diagnostic rates. The aim of our study is to evaluate the possibility of the presence of the disease in the dates before the diagnosis of COVID-19 in our country with imaging findings.

Materials and Methods: The first Covid-19 diagnosis in our country was made on March 11, 2020, and in our city on March 26, 2020. A total of patients whose thorax bt was taken in a period of 45 days from 26 March 2020 backwards and in the same period of the previous year were included in the study. The images were evaluated by two radiologists according to The Radiological Society of North America consensus statement. In order to evaluate the pre-existing disease with higher accuracy, the images were divided into two groups: 1) Typical and indeterminate, 2) Atypical and negative for pneumonia,

Results: Before the beginning of pandemic, there were a total of 502 patients who had chest CT scans, including 365 patients from 2019 and 137 patients from 2020. There was a statistically significant difference between negative for pneumonia subgroups of 2019 and 2020.

Conclusion: In our study, the number of patients with typical COVID-19 findings according to CT scans in the pre-pandemic period was determined similar to the previous year. This may be an indication that the disease has not started before the specified date in our country.

Keywords: computed tomography; COVID-19; diagnosis; disease reporting

Received: 24.10.2020, Accepted: 05.03.2021

${ }^{1}$ Kirikkale University School of Medicine, Department of Radiology, Kırıkkale, Turkey.
${ }^{2}$ Yerköy State Hospital, Department of Radiology, Yozgat, Turkey.
${ }^{3}$ Kirikkale University School of Medicine, Department of Internal Medicine, Kırıkale,Turkey.
Corresponding Author: Assoc. Prof. Adnan Özdemir, Kirikkale University School of Medicine, Department of Radiology, Kırıkkale ,Turkey.
e-mail: dradnanozdemir@ hotmail.com

How to cite: Özdemir A, Kömürcü Erkmen SP, Bekin Sarıkaya PZ, Karahan İ. The Evaluation of CT Images for COVID-19 Prior to Reporting of the First Case. Ahi Evran Med J. 2021;5(2):90-94. DOI: 10.46332/aemj.815746 


\section{INTRODUCTION}

Common symptoms of Coronavirus disease-19 (COVID-

19) infection are fever, cough, and dyspnea. In more severe cases, pneumonia, severe acute respiratory infection, kidney failure, and even death may occur. The whole world is struggling with this disease. ${ }^{1}$

Although the real-time reverse transcription polymerase chain reaction (RT-PCR) test is the gold standard for the diagnosis of COVID-19, computed tomography (CT) plays an important role in the diagnosis and staging of pneumonia. ${ }^{2,3,4}$ Typical CT findings of COVID-19 pneumonia are multifocal, ground-glass areas with peripheral and posterior distribution, predominantly lower lobe and mostly bilaterally located, with/without focal consolidations. For the challenge with COVID-19 pandemic, radiologists and physicians should be familiar with the imaging findings of COVID-19 pneumonia. ${ }^{5}$ Various algorithms have been created based on the CT findings. ${ }^{6}$ Various sensitivities and specificities of CT for COVID-19 were reported (60\% to $98 \%$ and $25 \%$ to $53 \%$, respectively). ${ }^{7,8,9}$ Besides, another study revealed that six of seven radiologists demonstrated $93-100 \%$ specificity in differing COVID-19 from other viral infections with CT. ${ }^{10}$

The first COVID-19 in our country case was diagnosed on March 11, 2020, and in our city on March 26, 2020. The aim of our study is to evaluate the possibility of the presence of the disease with imaging findings in the dates before the first COVID-19 case was reported in our country.

\section{MATERIALS and METHODS}

This retrospective study was conducted in Kırıkkale University Faculty of Medicine according to the principles of Declaration of Helsinki, Ethics Committee approval was taken from Ethics Committee of Kırrkkale University (Number:2020.05.06, Date:20/05/2020).

\section{Subjects}

The first diagnosis time in our city was March 26, 2020. All patients who had a chest CT scan between February 11, 2020, and March 26 (within 45 days period) were evaluated. As the second group, all patients who had chest CT scans in the same period for one year ago (between February 11, 2019, and March 26, 2019) were included. Two groups were compared in terms of demographics and CT findings.

\section{CT Imaging and Analysis}

Images were scanned with $\mathrm{CT}$ with 3-mm-thick slices with a Brilliance 64 scanner (Philips Medical System, Best, the Netherlands). All of the scans were obtained with routine thorax computed tomography imaging with no sedation being used for the procedures. All of the scans were obtained using the following parameters: tube voltage $=120$ $\mathrm{kV}$, effective $\mathrm{mAs}=80$, field of view $(\mathrm{FOV})=180 \mathrm{~mm}$, and image matrix $=768 \times 768$. The images were transferred to a commercially available Workstation.

For each patient, the chest CT scans were evaluated for the following characteristics: presence, amount, and distribution pattern of ground-glass opacities; the presence of consolidation; the presence of air bronchogram; the number of lobes affected where ground glass or consolidative opacities are present; the presence of nodules; the presence of pleural effusion; the presence of thoracic lymphadenopathy (defined as lymph node size > $10 \mathrm{~mm}$ in short axis size); airway abnormalities (including airway wall thickening, bronchiectasis, and endoluminal secretions), and presence of underlying lung diseases, such as emphysema or fibrosis. Also, opacities with a crazy-paving pattern, reverse halo sign, rounded morphology and intralesional cavitation, and linear opacities were noted.

All CT images were examined by two radiologists with approximately 10 and 5 years of experience, respectively, using an imaging console (AÖ, SPKE). Radiologists evaluated images of all patients according to The Radiological Society of North America (RSNA) consensus statement. ${ }^{11}$ RSNA consensus statement separated the images into four groups; typical appearance, indeterminate appearance, atypical appearance, and negative for pneumonia (Table $1)$. 
Table 1. Radiological Society of North America Expert Consensus Statement on Reporting Chest CT Findings Related to COVID-19.

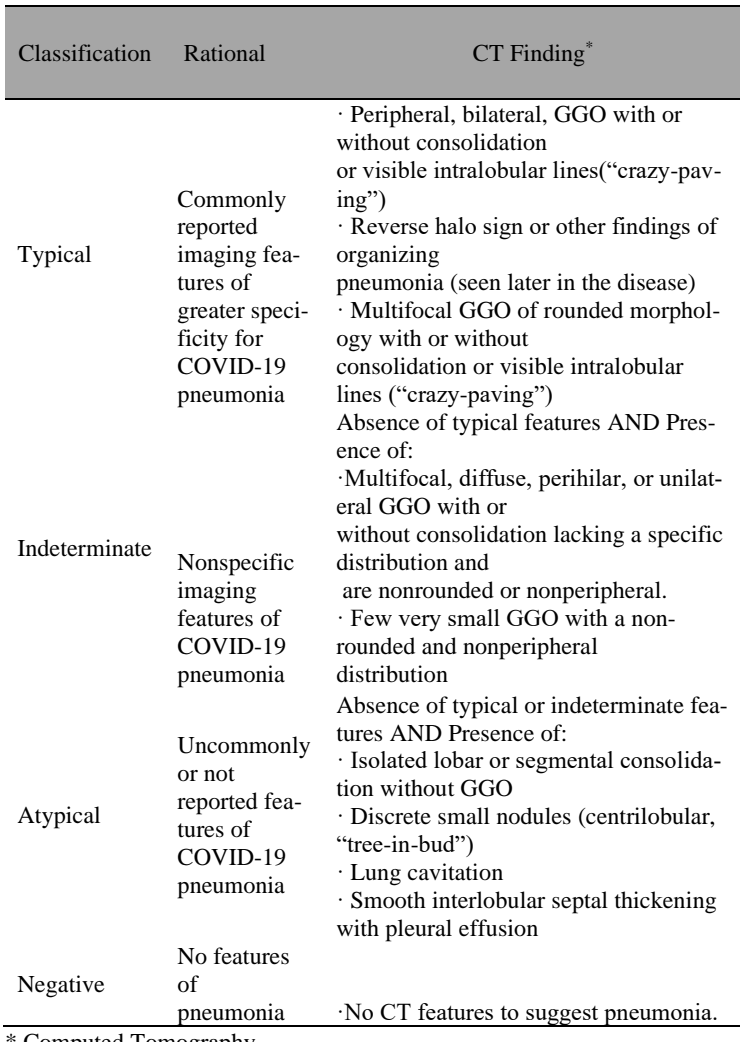

* Computed Tomography

In order to evaluate the pre-existing disease with higher accuracy, the patients were divided into two groups according to CT findings: Typical and indeterminate (High possibility group) and atypical and negative appearance for COVID-19 (Low possibility group). The two groups were compared according to the radiological classifications.

\section{Statistical Analysis}

IBM SPSS version 25 was used for all statistical analyses. Shapiro-Wilk test was used for detecting normal distribution. Mean \pm standard deviation was given for normally distributed continuous values, while the median (minimum-maximum) was given for not normally distributed values. The number of cases (n) and percentages (\%) were given for categorical variables. Mann-Whitney U test was used for comparison of groups that were not normally distributed continuous values. Chi-square and Fisher-exact tests were used for the comparison of categorical variables. $\mathrm{P}<0.05$ was accepted as statistically significant.

\section{RESULTS}

Chest CT scans of 502 patients were evaluated. There were 137 patients in the 2020 group, including 94 men and 43 women. Their mean age was $54.23 \pm 18.52$. There were 365 patients in the 2019 group, including 239 men and 126 women. Their mean age was $58.19 \pm 17.36$.

Chest CT scan performed in the first months of 2020 was 3.04 per day and 8.11 in 2019 ( $\mathrm{p}<0.001)$. The number of patients and rates according to the RSNA classification in both groups are given in Table 2.

Table 2. The distribution of CT findings according to RSNA classification.

\begin{tabular}{|c|c|c|c|c|c|}
\hline \multirow[t]{2}{*}{ Classification } & & \multicolumn{2}{|c|}{ Grup 2020} & \multicolumn{2}{|c|}{ Grup 2019} \\
\hline & & $\mathrm{n}$ & $\%$ & $\mathrm{n}$ & $\%$ \\
\hline \multirow{4}{*}{ RSNA $^{*}$} & $\begin{array}{l}\text { Typical appear- } \\
\text { ance }\end{array}$ & 1 & 0.7 & 5 & 1.4 \\
\hline & $\begin{array}{l}\text { Indeterminate ap- } \\
\text { pearance }\end{array}$ & 6 & 4.4 & 3 & 0.8 \\
\hline & & 32 & 23.4 & 35 & 9.3 \\
\hline & $\begin{array}{l}\text { Negative for } \\
\text { pneumonia }\end{array}$ & 98 & 71.5 & 322 & 88.5 \\
\hline Total & & 137 & 100 & 365 & 100 \\
\hline
\end{tabular}

According to the RSNA classification, the Negative for pneumonia subgroup shows those who do not have any findings in terms of pneumonia. Its rate in this group was $71.5 \%$ in 2020 , while it was $88.5 \%$ in 2019 . There was a statistically significant difference by comparison of the years $(\mathrm{p}<0.001)$.

When the high possibility group for COVID-19 (the typical and indeterminate subgroups) was compared with the low possibility group (atypical and negative for pneumonia subgroups), no significant difference was found between 2019 and 2020 (Table 3).

Table 3. The comparison of CT findings by years.

\begin{tabular}{|c|c|c|c|}
\hline & 2020 & 2019 & Sig \\
\hline $\begin{array}{l}\text { Low possibility } \\
\text { (Typical and indeterminate appear- } \\
\text { ances) }\end{array}$ & $\begin{array}{l}7 \\
(5.1 \%)\end{array}$ & $\begin{array}{c}8 \\
(2.2 \%)\end{array}$ & $\mathrm{p}=0.136$ \\
\hline $\begin{array}{l}\text { High possibility } \\
\text { (Atypical and negative for pneumonia) }\end{array}$ & $\begin{array}{c}130 \\
(94.9 \%)\end{array}$ & $\begin{array}{c}357 \\
(97.8 \%)\end{array}$ & \\
\hline
\end{tabular}




\section{DISCUSSION}

In the present study, a significant difference was noted in the number of chest CT scans between 2020 and 2019. This is because, in the first months of 2020, there may be a significant decrease in the number of hospital admissions due to the worldwide presence of Covid-19 disease. It is seen that the number of patients in the group without signs of pneumonia was significantly higher in 2019. This may indicate that the examinations taken in 2019 were performed without paying attention to the clinical indication or with overdiagnosis.

In our country, there are various discussions about the date when the COVID-19 diagnosis was first reported. It is possible to evaluate the accuracy of this date with CT images with high diagnostic rates.

The first COVID-19 diagnosis with PCR in our country was reported on March 11, 2020, and in our city on March 26, 2020. The travel history of the first COVID-19 patient and the new cases showed that these cases were imported from Europe. ${ }^{12}$ The first diagnosis dates reported in neighboring countries are earlier, those are February 19 in Iran $^{13}$, February 24 in Iraq ${ }^{14}$, February 26 in Georgia ${ }^{15}$ and February 27 in Greece. ${ }^{16}$ In our country, the first diagnosis is made later than in neighboring countries, which raises the question of whether it is due to the delay in the diagnosis process or the absence of any cases. In our study, no significant difference was found in terms of imaging findings between the period before the first COVID-19 diagnosis and the same periods of the previous year. The reasons why COVID-19 disease is seen later than neighboring countries in our country may be the measures taken in the early period. Numerous measures were implemented, including flight restrictions, 14-day isolation, and symptom monitoring for individuals who had travel histories from countries under risk. ${ }^{17}$ All these factors may support the accuracy of the history of the first COVID-19 diagnosis in our country.

Chest CT findings of COVID-19 can be confused with other diseases, especially other types of viral infections. ${ }^{10}$ It is thought that the findings supporting the infection process, which were observed at similar rates in both groups in the present study, may belong to pneumonia due to nonCOVID-19.

The study has major limitations. The data is valid for only one province, and it may not reflect the whole country's reality. In addition, the sample group was relatively small.

In conclusion, the number of patients with typical COVID19 CT findings was found similar to previous years, according to the presented study. This situation has revealed that COVID-19 can show similar properties with other viral infections. In addition, this result may be an indication that the disease does not begin earlier in our country before the reporting time. The pandemic is a process that needs fast actions and brings out challenges for all countries. Large-scale pandemics are expected in the future. The correct determination of the first diagnosis date is important in terms of obtaining the correct data. The statistical data, which is determined correctly, ensure that this date is reliable. In this way, predictions about the course of the disease are consistent, and the measures to be taken will be effective.

\section{Conflict of interest}

The authors declare that they have no competing interests.

\section{Financial Disclosure}

There are no financial supports.

\section{Authors' Contributions}

Concept/Design: AÖ, SPKE, PZBS. Data Collection and/or Processing: AÖ, SPKE, İK.. Data analysis and interpretation: AÖ, SPKE, PZBS, İK. Literature Search: AÖ, SPKE, PZBS, İK. Drafting manuscript: AÖ, SPKE, İK. Critical revision of manuscript: AÖ, SPKE, PZBS, İK. Supervision: AÖ, PZBS, İK.

\section{REFERENCES}

1. Tirmıkçığlu, Z. COVID-19 Enfeksiyonu Olan Gebelerde İlaç Kullanımı. Anadolu Klin. 2020;25(1):51-58.

2. Xu Z, Shi L, Wang Y, et al. Pathological findings of COVID-19 associated with acute respiratory distress syndrome. Lancet Respir Med. 2020;8(4):420-422.

3. Zhou F, Yu T, Du R, et al. Clinical course and risk factors for mortality of adult inpatients with COVID-19 
in Wuhan, China: a retrospective cohort study. Lancet. 2020;395(10229):1054-1062.

4. Xie X, Zhong Z, Zhao W, Zheng C, Wang F, Liu J. Chest CT for Typical Coronavirus Disease 2019 (COVID-19) Pneumonia: Relationship to Negative RT-PCR Testing. Radiology. 2020;296(2):41-45.

5. Ufuk F, Savaş R. Chest CT features of the novel coronavirus disease (COVID-19). Turk J Med Sci. 2020;50(4):664-678.

6. Nair A, Rodrigues J, Hare S, et al. A British Society of Thoracic Imaging statement: considerations in designing local imaging diagnostic algorithms for the COVID-19 pandemic. Clin Radiol. 2020;75(5):329334

7. Ai T, Yang Z, Hou H, et al. Correlation of Chest CT and RT-PCR Testing in Coronavirus Disease 2019 (COVID-19) in China: A Report of 1014 Cases. Radiology. 2020;296(2):32-40.

8. Wen Z, Chi Y, Zhang L, et al. Coronavirus Disease 2019: Initial Detection on Chest CT in a Retrospective Multicenter Study of 103 Chinese Subjects. Radiology: Cardiothoracic Imaging. 2020;2(2):200092.

9. Inui S, Fujikawa A, Jitsu M, et al. Chest CT Findings in Cases from the Cruise Ship "Diamond Princess" with Coronavirus Disease 2019 (COVID-19). Radiology: Cardiothoracic Imaging. 2020;2(2): 200110
10. Bai HX, Hsieh B, Xiong Z, et al. Performance of radiologists in differentiating COVID-19 from viral pneumonia on chest CT. Radiology. 2020;296(2):46-54.

11. Simpson S, Kay FU, Abbara S, et al. Radiological Society of North America Expert Consensus Statement on Reporting Chest CT Findings Related to COVID19. Endorsed by the Society of Thoracic Radiology, the American College of Radiology, and RSNA- Secondary Publication. J Thorac Imaging. 2020;35(4):219-227.

12. Koca F. Promotion of scientific research on COVID19 in Turkey. Lancet. 2020;396(10253):25-26.

13. World Health Organization, Islamic Republic of Iran situation. https://covid19.who.int/rgion/emro/coutry/ir Accessed 15 July, 2020.

14. World Health Organization Iraq situation. https://covid19.who.int/region/emro/country/iq Accessed 15 July, 2020

15. World Health Organization Georgia situation. https://covid19.who.int/region/euro/country/ge Accessed 15 July, 2020

16. World Health Organization Armenia Situation. https://covid19.who.int/region/euro/country/am Accessed 15 July, 2020.

17. Demirbilek Y, Pehlivantürk G, Özgüler ZÖ, et al. COVID-19 outbreak control, example of ministry of health of Turkey. Turk J Med Sci. 2020;50(SI-1):489494. 